\title{
Cooperation, the Crowding out Effect and the Role of Incentives in the Case of Sustainable Hydroplant Project in Brazil
}

DOI: 10.7595/management.fon.2018.0011

\begin{abstract}
Research Question: This paper sought to present a proposal for the analysis of the cooperation between a hydroelectric power plant and the fisheries community. Motivation: The use of economic experiments on the sustainability theme has been employed by adapting public goods games to the different realities faced by the players. For this research, focused on the environmental preservation, preferring to contribute/not to contribute to their preservation consists of public goods dilemmas. This subject also constitutes a research opportunity, since in the preliminary literature review few studies addressed concomitantly the sustainability question related to hydroelectric plants and the cooperation between them and a group of local stakeholders. Idea: The core idea of this paper was to bring a proposal of association between the behavioural economics and crowding out theory to the analysis of actions envisaging sustainability, which demand the cooperation between a hydroelectric power plant and the fisheries community that make a living out of its reservoir. Data: The research was conducted assessing documents such as Itaipu's annual sustainability reports and other documents between the plant and its stakeholders, in the environmental area, and in the form of contracts and cooperation agreements. Next, eight personal interviews were conducted with managers involved in the Sustainability Programme. Tools: With these information, the suggested public goods game was adapted from Fehr and Gachter (2000), and Sefton, Shupp and Walker (2007), and - for the present proposal of experiment - was named 'reservoir game', as the public goods in this case is Itaipu's plant reservoir. Findings: This study can help in the acquisition of relevant information about the applicability and efficiency of punishment and reward mechanisms related to cooperation, either in support of future negotiations and agreements or in bargaining situations when groups present their demands. One can only hope to have also contributed to the improvement of management of contractual agreements between corporations and local stakeholders in projects targeting sustainability, to reduce any transaction costs, and minimize the possibilities for conflict and disagreement between partners. Contribution: This paper expands existing research related to cooperation between a power plant and its local stakeholders.
\end{abstract}

Keywords: Public goods game, mechanisms of punishment and reward, sustainability, hydroelectric power plant, fishermen

JEL Classification: C93, Q01, L90

\section{Introduction}

In sustainability studies, we see an increasing number of technical analyses on the socio-environmental impacts caused by major corporations in the area of power generation (Morimoto, 2013; Liu et al., 2013; Jiang, Quiang and Lin, 2016). Given the magnitude, hydroelectric plants operate with a number of agents distributed by different areas such as energy generation, environment, and large-scale engineering projects, among others. Hydroelectric ventures, in their vast majority, promote sustainability actions with the support of local agents (groups of stakeholders). These are actually groups of interest which will be impacted by the activities developed by these ventures, as is the case of local business, fishermen, indigenous groups, riverside agriculturists, and other farmers (Brazil, 2015a). The multiple interactions point out to some interesting research possibilities. 
Moreira et al. (2015) and Jiang, Quiang and Lin (2016) observed that the themes related with the issues hydroelectric plants face - among which those on environmental management and sustainability - have become more attractive than the transformation technology itself, and that there is an interdisciplinary trend in research. Many of the projects addressing these themes are performed by the joint action of the interested parties (Bond et al. 2016; Soest, Stoop and Vyrastekova, 2016; Lin and Liu, 2016), guided by arrangements in the form of contracts, partnerships, or cooperative agreements, and the success of some of these initiatives require the involvement of two or more groups, and - sometimes - the results can only be checked in the medium and long term (Jin and Bai, 2011).

Since it is not always possible to carry out an immediate evaluation of the results of cooperation, Albers (2010) suggests the adoption of coordination, control, and incentive mechanisms with a view to adjusting the parties' behaviour. Among the types of incentive, the use of reward or punishing mechanisms stand out as instruments capable of motivating those involved in cooperating (Sefton, Shupp and Walker, 2007; Egas and Riedl, 2008; Balliet, Langer and Mulder, 2011). On the other hand, some studies indicate that the use of external incentives can compromise the intrinsic motivation of those involved (Vollan, 2008; Narloch, Pascual and Drucker, 2012). In this scenario, some research strands may be useful in evaluating these interactions, such as the behavioural economic game theory, and the crowding out theory, offering subsidies to help us understand how such groups make their decisions, and particularly how they choose to cooperate (Cardenas and Ostrom, 2004; Sturm and Weimann, 2006; Lozano, 2007; Soest, Stoop and Vyrastekova, 2016).

In the context of this research, focused on the sphere of sustainability and environmental preservation, preferring to explore/not explore non-renewable resources, or contribute/not to contribute to their preservation, consists of dilemmas on public commodities, once "the public resource dilemma is highly focused on in today's global society, because it determines how long we will hold those necessary resources for the sustainable development" (Du, Wu and Wang 2016, p.1432). Faced with the difficulties of reconciling different stakeholder interests, as regards local contribution, opportunities for local development, reduction of environmental risks, private interests, and other such tensions between the Corporation and Society (Porter and Kramer, 2006), the contributions of these two theoretical strands as a mechanism for future negotiations, bargaining, and contract improvements needs to be envisioned. It is argued that recognizing the determinants weighing on the decision-making process of these groups to cooperate and trust can be deemed fundamental, particularly in moments of negotiation and bargaining among the involved, as well as providing information for the improvement of contractual instruments establishing the relationships between stakeholders and the Plant, and to minimize the possibilities of conflict and mismatched expectations between all involved.

This subject also constitutes a research opportunity, since in preliminary literature review few studies addressed concomitantly the sustainability question related to hydroelectric plants and the cooperation between them and a group of local stakeholders, based on behavioural economics and crowding out theory approaches. The present study hence seeks to bring a proposal of association between two areas of research still poorly integrated - the contributions that behavioural economics and crowding out theory can bring to the analysis of actions envisaging sustainability, which demand the cooperation between a hydroelectric power plant and the fisheries community that make a living out of its reservoir. The use of economic experiments on the sustainability theme has been employed by adapting public good games (both in the form of voluntary contribution mechanism and common pool resources) to the different realities which the players actually face. Usually, the themes are focused on environmental preservation and control of scarce natural resources. We can name the forestry game (Cardenas, Janssen and Bousquet, 2013; Janssen et al., 2012); the water irrigation game (Janssen et al., 2012; Cardenas, Janssen et al. 2013); and the fishery game (Castillo et al., 2011; Emery et al., 2015).

Considering the above, the problem of this research can be described as follows: how can behavioural economics, through the use of incentive mechanisms, contribute to assessing the intention of cooperation and the effect of crowding out between a hydroelectric power plant and a group of local stakeholders in projects favouring sustainability? The text begins with the literature review, followed by the construction of a proposal, after which our closing considerations are presented.

\section{Theoretical Review}

\subsection{Sustainability and energy}

It is recognized that corporations cause impact in the surroundings of their operation, and that cautionary attention to these impacts becomes absolutely necessary, particularly in the social, economic, and environmental spheres. In this context, much has been discussed about the need for corporations to address 
the subject of sustainability, not only as an accessory matter, but incorporating it on strategic decision-making processes (Engert, Rauter and Baumgartner 2016; Moreira et al., 2015), either to mitigate/avoid social and environmental impacts, to explore new markets, or to reconcile the interests of various stakeholders (Zijp et al. 2015; Morrison-Saunders et al., 2014). These latter authors maintain that this perspective envisages a better understanding of sustainability assessment processes, transparency, and - particularly - the potential way of obtaining consensus.

In the energy sector, it is noted that many ventures sometimes delay their operation due to disagreement between stakeholders, particularly regarding the release of environmental licenses, and clashes with local communities (Brazil, 2015a). Despite these obstacles, this sector is considered fundamental for the functioning of mostly all other sectors in economy, so that the availability of energy conditions the capacity of a country to provide several services to its population, and for it to prosper economically (Yüksel, 2010; Mayumi and Tanikawa, 2012; Purwanto and Afifah, 2016). In this respect, the global energy demand rises more slowly than in the past but still should expand by 30\% between 2017 and 2040 (International Energy Agency, 2017).

\subsection{Hydroelectric power plants}

Jiang, Quiang and Lin (2016), and Han et al. (2014) found, from the bibliometric studies, that (i) most research is linked to a period following construction and start of operation, rather than to construction projects and technologies; (ii) the themes are multidisciplinary; (iii) there is a fast and rapid growth of publications on hydroelectric power plants. The argument is the relevance of hydroelectric power plants as a source of renewable energy, and its relative low-cost, when compared to other potential power sources (Liu et al., 2013). The benefits of using these plants when compared to other sources, is pointed out by (Yüksel, 2010; Liu et al., 2013):

- Extension of flooded areas in some regions;

- Efficiency of energetic conversion, due to low-cost operation and technology already in place;

- Low maintenance costs;

- Major input (water) is not subject to fluctuations due to market changes;

- Possibility of flexible operation in power generation;

- Capacity to promote improvement in the living conditions of local communities surrounding these large plants;

- High level of reliability.

In Brazil, such has been the main source of power supply, besides thermal plants, wind-power plants, small hydroelectric plants, and nuclear power plants (Brazil, 2015a). Moreira et al. (2015) state that the growth rate of the energy sector in Brazil is $4 \%$ / year, considering the increased participation of other energy sources in the Brazilian energy matrix. Compared to the other countries of the emerging economies, there are some differences: coal-fired power plants still represent the main source of power supply in South Africa, China and India, while in Russia natural gas thermoelectric plants are the most used (Brazil, 2015b).

Due to the size of these projects and their impact on the environment, the actions toward sustainability proposed by the hydroelectric plants are often under debate. Most of these actions include economic, social, and environmental evaluations (Liu et al., 2013): local impact, the constraints that these projects may occasion in ecosystems and local communities, changes to the dynamics of the aquatic and terrestrial habitat and the deposit of sediments in river beds are all considered, among others (Yüksel, 2010; Zhao et al., 2012). In the words of Jiang, Quiang and Lin (2016, p.235):

Hydropower will orient the development strategy of renewable energy due to its huge development potential, economic and social benefits and proven technology. However, we cannot omit the negative impacts brought by hydropower projects in terms of environment, ecology and socio-economy.

In Brazil, there are some plants with a huge power-generation capacity. Among the largest, we can mention Itaipu Binational (14,000 MW), Belo Monte (11,233 MW), Tucuruí (8,370 MW), and Jirau (3,750 MW) (Brazil, 2015a). Given the particularities of the country in terms of availability of hydric resources, the main topics of discussion are: (a) reduction of local and global impact arising from the use of energy sources; (b) use of renewable sources; (c) minimization of impact on the environment; (d) discussions, at the national and international level, on climate change. Regarding socio-environmental themes, the following topics can be mentioned: (a) environmental impact: loss of native vegetation; transformation of a lotic environment into a lentic one (running waters into dammed waters, creation of reservoirs), loss of vegetation; (b) social-economic impact: affected population; interference in indigenous lands; (c) interference in infrastructures; (d) socio-economic benefits: job creation, temporary increase in tax-collection, permanent increase in tax-collection. 
There are several bodies involved in the decision-making process in the power generation sector, each bringing to the table their own interests and responsibilities. The following table summarizes the main stakeholders in the sector:

Table 1: Main stakeholders in the sector

\begin{tabular}{|l|l|}
\hline \multicolumn{1}{|c|}{ STAKEHOLDERS } & \multicolumn{1}{c|}{ TYPE OF INVOLVEMENT } \\
\hline $\begin{array}{l}\text { National Electric Energy } \\
\text { Agency }\end{array}$ & $\begin{array}{l}\text { Definition and evaluation of technical requirements for the } \\
\text { concession of building and operation licenses }\end{array}$ \\
\hline $\begin{array}{l}\text { National Electric } \\
\text { Systems Operator an } \\
\text { Enamber of Electric }\end{array}$ & Regulation, auctions of new projects, dispatch of energy and sales \\
\hline Energy Research Office & Development of prospective studies on new projects in the area \\
\hline Local government & $\begin{array}{l}\text { Support to local projects in relation to social, environmental, and } \\
\text { economic impact, matters related with tax-collection. }\end{array}$ \\
\hline Stakeholders and investors & $\begin{array}{l}\text { Make their decisions based on economic, social, and } \\
\text { environmental restrictions imposed by the market, regulating } \\
\text { agencies, and other stakeholders. }\end{array}$ \\
\hline $\begin{array}{l}\text { Brazilian Institute of } \\
\text { the Environment and } \\
\text { Renewable Natural Resources } \\
\text { and other local agencies }\end{array}$ & $\begin{array}{l}\text { Definition and evaluation of the environmental requirements for the } \\
\text { concession of building and operation licenses }\end{array}$ \\
\hline Society & $\begin{array}{l}\text { Involvement in matters related to economic, social, and } \\
\text { environmental aspects and particularly in local issues, close to } \\
\text { corporations and encompassing groups of fishermen, riverside } \\
\text { farmers, and adjacent residents }\end{array}$ \\
\hline
\end{tabular}

Source: Adapted from Moreira et al. (2015).

On the whole, many of the actions developed in the scope of sustainability occur by means of the interaction between power plants and their surrounding environment. At this point, we would add that understanding the evolution of cooperation among individuals and groups is still an interdisciplinary challenge (Perc and Wang, 2010), and behavioural economics can contribute to this endeavour.

\subsection{Behavioural economics, the crowding out effect}

Behavioural economics consists of a fairly recent field of research deriving from the incorporation of economics, theoretical developments, and empirical findings in the fields of human and social sciences (Weber and Dawes, 2005). Among the possibilities of contribution of this theoretical strand, we can mention behavioural economic experiments, and the public goods game in particular (Sturm and Weimann, 2006; Lozano, 2007; Soest, Stoop and Vyrastekova, 2016).

The public goods game consists of an experiment in which the agents receive a certain amount of money and can contribute with the purpose of maintaining public goods or taking the money for themselves (for personal benefit), being that no agent can be excluded of enjoying the benefits the public goods offer. The donated value usually doubles (or is multiplied by another pre-established index) and redistributed equally to all players, independently of their individual contribution. The game presupposes the existence of an individual or group dilemma and the possibility of contributing/not contributing but still being able to use the public goods (Sell et al. 2002; Soest, Stoop and Vyrastekova, 2016). The payoff represents the linear function of the contribution of the subjects, and therefore the aggregated returns are maximized if each subject invests all his patrimony in a public good, so that the amount contributed to the public account represents a measure of the participant's cooperativity (Cardenas and Carpenter, 2006). However, the self-reward maximizing strategy in this game is to pocket the donation independently of the amounts contributed by the other members of the group (Soest, Stoop and Vyrastekova, 2016). This behaviour adopted by a subject, to maximize the use of the public goods without contributing to the provision of the same is recognized as free riding (Andreoni 1988; Sturm and Weimann, 2006).

Some authors argue that the public goods game consists of a feasible possibility to evaluate the willingness of the participating agents to cooperate with a view to sustainability (Lozano 2007; Soest, Stoop and Vyrastekova, 2016; Robert and Broman, 2017). Still, a strand of studies on cooperation argues for the need to consider local collective construction of solutions to specific environmental issues (Frey and Stuzer, 2006; Vollan, 2008). Cardenas, Stranlund and Willis (2000) and Cardenas and Ostrom (2004) analysed the effect of governmental intervention to regulate wood extraction in Colombia. Recognizing that the extraction of this 
material accelerates local erosion, the authors - considering the neoclassic economic theory - hoped that regulation would bring better results to local groups. Nevertheless, they discovered that when the extraction was marked by informal norms defined by the residents themselves, the decision to extract was balanced between selfish and collectivist behaviours. From the moment the government took over this responsibility, the residents no longer felt co-responsible for the extraction, adopting a more egocentric posture.

Comparatively, both transaction cost theory and agency theory consider monitoring and surveillance to raise partner's efforts, while the literature on the crowding out effect suggests just the opposite (Dickinson and Villeval, 2008). Frey and Jegen (2001), and Fehr and Falk (2002) reinforce this finding, stating that individuals can reduce their willingness to cooperate when threatened by sanctions/punishment, or even by economic incentives and rewards.

\subsection{The role of reward and punishment mechanisms}

In order to encourage cooperation between individuals, some authors suggest the use of reward mechanisms (for cooperation) and punishment (for non-cooperation) as tools to promote cooperation in social dilemmas or situations when immediate self-interest and longer-term collective interest conflict (Balliet, Langer and Mulder, 2011; Choi and Ahn, 2013).

The reward mechanisms, from the perspective of the public goods game, consist of an artifice used to promote cooperation between the parties, being effective in games of more than one round (Walker and Halloran, 2004), and when the cost of promoting it is lower than the benefit of the recipient (Sefton et al., 2007), being recommended the use of this instrument individually (Narloch et al., 2012). For the latter authors (2012, p.2014): "by raising the individual pay-offs and decreasing free-riding incentives, individual rewards could have a stabilizing effect on collective action due to motivating people to stick to the social norm". As with the agency theory, it is suggested that the partner is motivated by the financial returns from the interactions, so that the higher the return, the greater the likelihood of the agent to adopt a cooperative posture (Dickinson and Villeval, 2008).

The following table summarizes some of the results related to rewards in the public goods game:

Table 2: Synthesis of the studies addressing rewarding in public goods games

\begin{tabular}{|c|c|c|}
\hline Themes & Observations & Authors \\
\hline Interactions/rounds question & $\begin{array}{l}\text { - Reward is only effective in games with } \\
\text { successive interactions; }\end{array}$ & $\begin{array}{l}\text { Walker and Halloran, } \\
\text { (2004); Balliet, Langer and } \\
\text { Mulder (2011) }\end{array}$ \\
\hline $\begin{array}{l}\text { Collective and individual } \\
\text { reward, and crowding out } \\
\text { effect }\end{array}$ & $\begin{array}{l}\text { - Collective reward is ineffective and tends to } \\
\text { reduce motivation for cooperation } \\
\text { - Individual reward is effective, and tends to } \\
\text { stimulate cooperation; }\end{array}$ & $\begin{array}{l}\text { Gneezy et al. (2011); } \\
\text { Travers et al. (2011); } \\
\text { Narloch Pascual and } \\
\text { Drucker (2012) }\end{array}$ \\
\hline $\begin{array}{l}\text { Reward, empowerment of } \\
\text { local groups, and crowding } \\
\text { out effect }\end{array}$ & $\begin{array}{l}\text { - Policies developed to reward local stakeholders } \\
\text { cooperative behaviour will be more effective if } \\
\text { they allow local groups to be responsible for local } \\
\text { decisions, otherwise local stakeholders tend to } \\
\text { cease cooperation }\end{array}$ & Travers et al. (2011) \\
\hline $\begin{array}{l}\text { Non-monetary reward } \mathrm{x} \\
\text { cooperation }\end{array}$ & $\begin{array}{l}\text { - The experience of being praised (social reward) } \\
\text { does not lead to increased cooperation in the next } \\
\text { round }\end{array}$ & Kumakawa (2013) \\
\hline Unit reward $x$ cooperation & $\begin{array}{l}\text { - When the reward rate and its costs are } 1: 1 \text {, the } \\
\text { reward mechanism is not capable of maintaining } \\
\text { cooperation, regardless of the number of rounds }\end{array}$ & $\begin{array}{l}\text { Walker and Halloran } \\
\text { (2004); Sefton, Shupp and } \\
\text { Walker (2007) }\end{array}$ \\
\hline $\begin{array}{l}\text { Positive rewards } x \\
\text { cooperation }\end{array}$ & $\begin{array}{l}\text { - Positive rewards (1:5) produce a stronger impact } \\
\text { on cooperation than unitary rewards; } \\
\text { - When the impact of the reward is significant in } \\
\text { cooperation, its use is more frequent }\end{array}$ & $\begin{array}{l}\text { Andreoni, Harbaugh and } \\
\text { Vesterlund (2003); } \\
\text { Vyrastekova and Soest } \\
(2008)\end{array}$ \\
\hline
\end{tabular}

Source: Prepared based on the literature review

Regarding punishment mechanisms, Reuben and Riedl (2013) broaden the discussion about contributions to a public good, indicating that differences in contribution stem from the forms of punishment imposed, so that when there is no punishment, all involved converge to the free riding behaviour. Regarding this finding, other authors (Masclet et al., 2003) have also observed that when the punishment is monetary, offer increases more than when the punishment is non-monetary. Meanwhile, for both possibilities, when the punishment is removed, the contributions decrease in the public goods game. 
While the prediction of punishment in contractual arrangements is interpreted as a mechanism of prevention of opportunistic behaviours (Willianson, 1985), in experiments of public goods game, it is observed as the prediction of punishment as a mechanism envisaging to ensure efficiency/contribution of the good (Fehr and Gaechter, 2000; Sefton et al., 2007) penalizing those who choose not to cooperate, although they can still enjoy that specific public good.

In this context, we can observe some authors' reserve in what concerns the magnitude of the punishment, recommending that - to be effective - punishment should be high, in a proportion 1:3 or even higher (Sefton et al., 2007; Nikiforakis and Normann, 2008; Chaudhuri, 2010): the mere prediction of a punishment, or a punishment with minimal loss to the player, would not be effective to cooperation. It should be noted that the use of this resource is recommended, making the application of punishment low-cost to the punisher, and of high impact to those punished (Carpenter, 2007; Egas and Riedl, 2008; Nikiforakis and Normann, 2008). The following table synthesizes some of the main findings regarding punishment mechanisms in public good games.

Table 3: Synthesis of the studies addressing punishment

\begin{tabular}{|c|c|c|}
\hline Themes & Observations & Authors \\
\hline $\begin{array}{l}\text { Violation of norms } \\
\text { vs. punishment }\end{array}$ & $\begin{array}{l}\text { Punishment is accepted when norms of justice and norms of } \\
\text { cooperation are violated, being voluntary or provided for in a } \\
\text { contract. }\end{array}$ & $\begin{array}{l}\text { Dominique et al. (2000); } \\
\text { Choi and Ahn, (2013) }\end{array}$ \\
\hline $\begin{array}{l}\text { Conditions to } \\
\text { punish }\end{array}$ & $\begin{array}{l}\text { The conditions for altruistic punishment must be relatively } \\
\text { favourable (low-cost for the punisher and high impact for the } \\
\text { punished) for the cooperation to be maintained }\end{array}$ & $\begin{array}{l}\text { Egas and Riedl (2008); } \\
\text { Nikiforakis and Normann } \\
\text { (2008) }\end{array}$ \\
\hline $\begin{array}{l}\text { Return of the } \\
\text { punished player }\end{array}$ & $\begin{array}{l}\text { When a punished player returns from the penalty applied, } \\
\text { cooperation tends to die out faster }\end{array}$ & Nikiforakis (2004) \\
\hline $\begin{array}{l}\text { Free rider behaviour } \\
\text { and punishment }\end{array}$ & $\begin{array}{l}\text { With the prediction of punishment, free riding behaviour is } \\
\text { inhibited }\end{array}$ & $\begin{array}{l}\text { Fehr and Gaechter } \\
\text { (2000), Bochet, Page } \\
\text { and Putterman (2006); } \\
\text { Sefton et al. (2007) }\end{array}$ \\
\hline $\begin{array}{l}\text { Face-to-face } \\
\text { communication vs. } \\
\text { punishment }\end{array}$ & $\begin{array}{l}\text { Comparing the efficiency of face-to-face communication with } \\
\text { predicted punishment, we can observe that communication } \\
\text { increases contribution more than the possibility to punish, and } \\
\text { considering the cost of punishing, only communication } \\
\text { significantly increases the gains of individuals and the group }\end{array}$ & $\begin{array}{l}\text { Bochet, Page and } \\
\text { Putterman (2006) }\end{array}$ \\
\hline $\begin{array}{l}\text { Conditional } \\
\text { cooperation }\end{array}$ & $\begin{array}{l}\text { Conditional cooperating partners are often willing to punish free } \\
\text { riders, even if there is a cost and it does not confer long-term } \\
\text { benefits }\end{array}$ & $\begin{array}{l}\text { Falk et al., (2005); } \\
\text { Gächter, Gächter et al. } \\
\text { (2008) }\end{array}$ \\
\hline $\begin{array}{l}\text { Efficiency vs. } \\
\text { punishment }\end{array}$ & $\begin{array}{l}\text { - Both contributions as regards the efficiency of a public good are } \\
\text { larger when punishment is allowed than when it is not foreseen; } \\
\text { - Without the possibility of punishment, 'homogeneity vs. } \\
\text { heterogeneity' does not matter, since free riding behaviour arises } \\
\text { and will increase over time }\end{array}$ & $\begin{array}{l}\text { Rockenbach and } \\
\text { Milinski (2006); Reuben } \\
\text { and Riedl (2013) }\end{array}$ \\
\hline $\begin{array}{l}\text { Punishment vs. } \\
\text { number of rounds }\end{array}$ & In single round games, punishment has no effect & $\begin{array}{l}\text { Walker and Halloran } \\
\text { (2004); Gächter et al. } \\
(2008)\end{array}$ \\
\hline $\begin{array}{l}\text { Magnitude of } \\
\text { punishment vs. } \\
\text { cooperation }\end{array}$ & $\begin{array}{l}\text { - When punishment is small (as in } 1: 1 \text { ) it is not effective in } \\
\text { maintaining cooperation; } \\
\text { - To ensure group efficiency, punishment must be high (1:4) }\end{array}$ & $\begin{array}{l}\text { Sefton et al. (2007); } \\
\text { Nikiforakis and Normann } \\
\text { (2008); Chaudhuri } \\
\text { (2010) }\end{array}$ \\
\hline $\begin{array}{l}\text { Size of the group vs. } \\
\text { punishment }\end{array}$ & $\begin{array}{l}\text { When full monitoring is allowed, the size of the group tends to } \\
\text { increase contribution, considering better monitoring of free riders }\end{array}$ & Carpenter (2007) \\
\hline Cost of punishment & $\begin{array}{l}\text { Interest in punishment decreases as the cost of punishment } \\
\text { increases, as in the law of supply and demand }\end{array}$ & $\begin{array}{l}\text { Anderson and } \\
\text { Putterman (2006) }\end{array}$ \\
\hline $\begin{array}{l}\text { Social punishment } \\
\text { vs. antisocial } \\
\text { punishment }\end{array}$ & $\begin{array}{l}\text { In the possibility of choosing between punishing free riders or } \\
\text { those who contribute well above average, punishing free riders is } \\
\text { chosen }\end{array}$ & $\begin{array}{l}\text { Hermann et al. (2008); } \\
\text { Ertan et al. (2009) }\end{array}$ \\
\hline $\begin{array}{l}\text { Punishment vs. } \\
\text { contract writing }\end{array}$ & $\begin{array}{l}\text { Punishment is best applied to contracts that require full } \\
\text { cooperation. In contracts that require a minimal level of } \\
\text { cooperation, punishment tends to become inefficient. }\end{array}$ & Dannenberg (2016) \\
\hline $\begin{array}{l}\text { Non-monetary } \\
\text { punishment }\end{array}$ & $\begin{array}{l}\text { - Non-monetary punishments may increase cooperation for a } \\
\text { limited period of time; } \\
\text { - These punishments are more effective among people one } \\
\text { knows, rather than with strangers; } \\
\text { - Both forms of punishment are more efficient for cooperation } \\
\text { than not having any punishment at all. }\end{array}$ & Masclet et al. (2003) \\
\hline
\end{tabular}


In view of the above, in order to propose contributions of incentive mechanisms to cooperation in the field of sustainability for a specific group of Itaipu's stakeholders, as well as evaluate the manifestation of the crowding out effect, it is necessary to glimpse on how such motivations and collective constraints associated to incentives aimed at environmental preservation affect individual decisions to contribute to the public good.

\section{Methodological Procedures and Construction of The Proposal for Applying The Public Goods Game}

The proposal for the integration of the themes is illustrated here in the form of Itaipu hydroelectric plant and its particular Sustainability Program. The choice was intentional, once the corporation is considered to be the largest power generating hydroelectric in the world, with its sustainability program in force for over a decade, being internationally recognized for its contribution to the socio-economic development of the Western region of the Parana State, and for its water management and conservation practices. The operation of this plant began in 1984. Its reservoir is $170 \mathrm{~km}$ long, and 20 power units generating $700 \mathrm{MW}$ each were installed. This is a binational hydroelectric power plant (Brazil and Paraguay), and this research was conducted only on the Brazilian side. Another criterion for choice was that their programme has several fronts of interaction with groups of local stakeholders. The following table presents the generation of energy for the last ten years.

Table 4: History of power generation at the Itaipu hydroelectric power plant

\begin{tabular}{|c|c|c|c|c|c|c|c|c|c|c|}
\hline Year & 2008 & 2009 & 2010 & 2011 & 2012 & 2013 & 2014 & 2015 & 2016 & 2017 \\
\hline $\begin{array}{l}\text { Total } \\
\text { GWz }\end{array}$ & 94.685 & 91.652 & 85.303 & 91.523 & 97.533 & 97.878 & 87.165 & 88.575 & 102.335 & 96.387 \\
\hline
\end{tabular}

Source: Elaborated through data collation

The research was conducted assessing documents such as Itaipu's Ten-Year Energy Plan (Brazil, 2015a), the plant's annual sustainability reports, and other documents between the plant and its stakeholders, in the environmental area, and in the form of contracts, service permits, partnerships, and cooperation agreements. The purpose was to contextualize the main initiatives aimed at environmental preservation that require participation of the community of professional fishermen using the reservoir, the timeframe of these relationships, types of results expected, and whether the participation was a demand from the stakeholders. We are discussing a population of 456 professional fishermen, divided by 10 locations/fisheries associations. The following figure shows their distribution along Itaipu's reservoir.

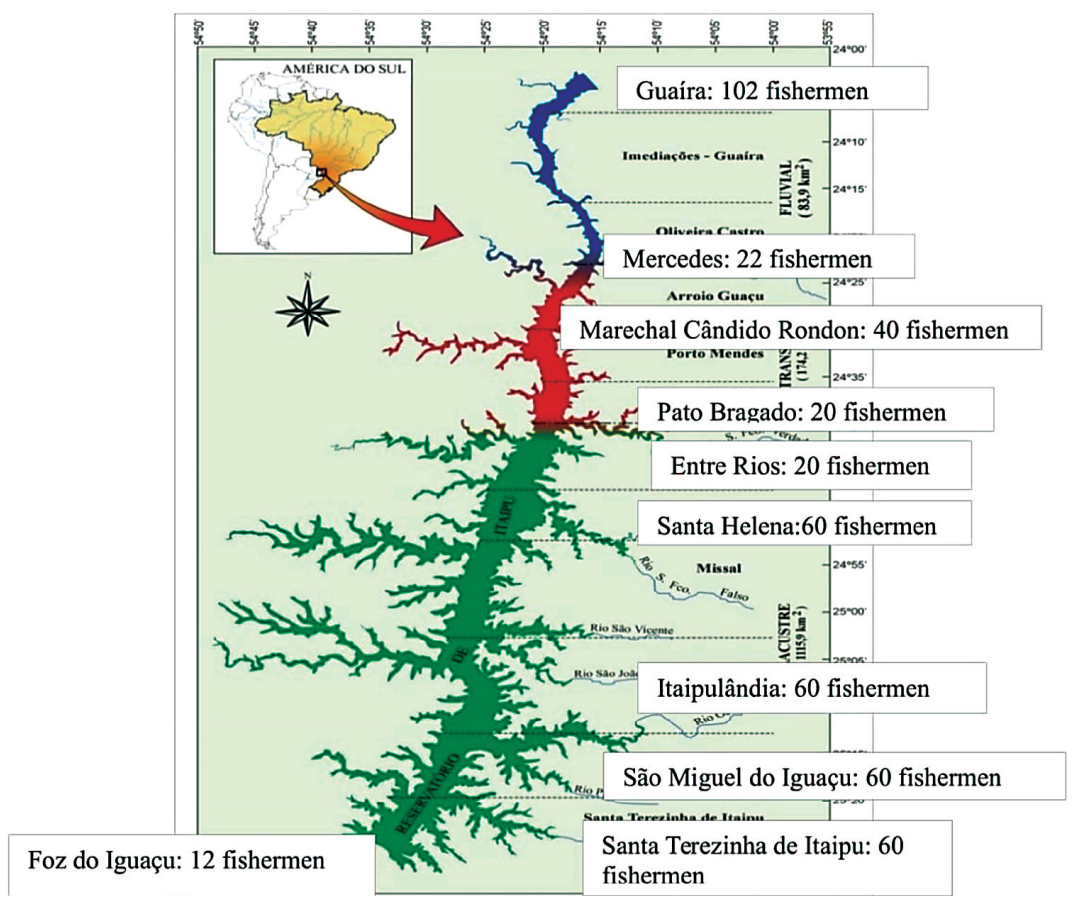

Figure 1: Distribution of professional fishermen along the reservoir 
Next, eight personal interviews were carried out with managers involved in the Sustainability Program, guided by a semi-structured script of qualitative questions (Godoy, 2006) - whose contents included the validation of the researcher's findings from the examination of secondary documents, as well as the explanation regarding the fishermen of the Western region of Parana identified as relevant to the power plant, the particularities of each project developed, and the risks of possible non-cooperation. The questions also explored topics related to management of relationships, determinants and obstacles. The understanding of these questions was relevant to initially propose the field experiment in the form of public goods game. Subsequently, it will also support the definition of the experiment protocol to be used with fishermen.

The suggested public goods game was adapted from Fehr and Gachter (2000), and Sefton, Shupp and Walker (2007), and - for the present proposal of experiment - was named 'reservoir game', as the public good in this case is Itaipu's plant reservoir. The option stems from the fact that the Itaipu reservoir provides the input used to generate the energy that supplies approximately $17 \%$ of the energy in the whole of Brazil. Besides, this reservoir serves many purposes for the region population: it serves as the source of water for the household consumption, for agriculture and livestock; as a tourist attraction; and as a source of subsistence for the fishing activities in the region.

The proposal for this game consists of conducting the experiment with groups of six players each. With each round, the players must receive 2 envelopes and 10 coins of $R \$ 1$ each, choosing how many coins to allocate to a 'public account created for the preservation of the reservoir' (first envelope), and how many coins to allocate to their respective 'private accounts' (second envelope). Unlike the allocation of coins to the individual account of each player, those donated for the reservoir preservation are summed, and right after multiplied by 2 (representing the benefits resulting from the preservation of the reservoir) and redistributed equally among all players, to illustrate the characteristics of a public good (non-exclusive and non-competing). The results should be presented in a projector, round by round, so that each player can take note of their gains, and the gains of the other players.

After 6 rounds, the possibility of one player punishing or rewarding another must be introduced. For this sequence (another 6 rounds), an extra envelope must be handed out. In this envelope the player writes the number of the player he/she would like to punish (or reward) and with how many coins. In addition to the rest of the rules, for each coin the player uses to punish (or reward), the punished player loses (or receives) 4 coins, representing a high punishment (or reward) as suggested in the specialized literature (Sefton et al., 2007; Nikiforakis and Normann, 2008; Vyrastekova and Soest 2008; Reuben and Riedl, 2013). At the end of the 6 rounds, there should be a draw for each player and - in that lot - the player would keep all the money.

It can be said that experiments of this nature, in turn, test hypotheses related to the free rider behaviour and the selfish choice (Soest et al., 2016) of the players as a presupposition of neoclassical economics; the role of the mechanisms of punishment and reward to ensure efficiency of public good in cooperation (Fehr and Gaechter, 2000); and the potential changes to cooperative behaviour (materialized in donations) resulting from the institution of penalties or rewards, i.e., whether the sustainability of the Itaipu's plant reservoir represents a motive good enough to favour cooperation on its own (Bowles and Reyes, 2013).

\subsection{Selection of players and definition of games}

The criteria for identification and selection of potential players in this proposal was based on the identification - among those groups belonging to the local society - of those who frequently interact with the power plant. These are stakeholders with frequent interface relationships, particularly with the area of environment and environmental management. The following was also considered:

- That the fishing community has - direct or indirect - contact with some contractual regiment. This point constitutes an attribute for cooperation: when the participants themselves agree to a work order and a punishment system, it is often not necessary to use it, and the benefits of cooperation can be substantially improved (Ostrom, 2010);

- That the fishermen represent a group of interest mentioned in Brazilian electrical sector official documents (Brazil, 2015a) and in continual assessment for the construction of economic, social, and environmental indicators (IHA, 2006; Morinoto, 2013; Dombi et al., 2014) for hydroelectric plants;

- That from the suggestion of the criteria for classification of stakeholders, relation of dependency (Langtry, 1994) and of legitimacy in the relationship (Cornell and Shapiro, 1987; Carrol, 1989) of the professional fishermen to the power plant were observed; 
- That these are mostly low-income groups whose decisions that may benefit them in the short-term may overlap with long-term cooperation decisions, albeit to the detriment of sustainability and contractual regiment. On the other hand, the imposition of external incentive mechanisms may undermine motivation of these groups to preserve the referred public good;

The follwoing table characterizes the stakeholders identified from the data collection.

Table 5: Characterization of the fishing community

\begin{tabular}{|c|c|c|c|}
\hline Stakeholder & Characterization & Stakeholder relevance to Itaipu & $\begin{array}{l}\text { Problems of possible } \\
\text { non-cooperation }\end{array}$ \\
\hline Fishermen & $\begin{array}{l}\text { Predominantly } \\
\text { descending from } \\
\text { traditional riverbank } \\
\text { communities, fishing } \\
\text { in the reservoir being } \\
\text { their livelihood. }\end{array}$ & $\begin{array}{l}\text { - As they survive from a resource } \\
\text { offered by the reservoir, they } \\
\text { become fundamental for its } \\
\text { preservation; } \\
\text { - They cooperate in research and } \\
\text { monitoring activities normally } \\
\text { carried out by ITAIPU in its reservoir; } \\
\text { - They cooperate in campaigns to } \\
\text { clean the reservoir, acting as } \\
\text { environmental agents that help raise } \\
\text { awareness of local communities; } \\
\text { - They develop, in partnership with } \\
\text { Itaipu, aquaculture activities to } \\
\text { complement their income; } \\
\text { - They develop joint actions, in } \\
\text { which Itaipu helps with the transfer } \\
\text { of technology to process and } \\
\text { aggregate value to fisheries; }\end{array}$ & $\begin{array}{l}\text { - Discontinuity in provision of } \\
\text { information compromises } \\
\text { monitoring of fishing resources } \\
\text { and socioeconomic data in the } \\
\text { long run. } \\
\text { - The risk of lawsuits against the } \\
\text { power plant, alleging material } \\
\text { damages arising from the } \\
\text { construction of a reservoir; } \\
\text { - Pollution of the reservoir due to } \\
\text { accumulation of dumped } \\
\text { garbage; } \\
\text { - Contamination of the reservoir. }\end{array}$ \\
\hline
\end{tabular}

Source: Prepared based of the literature review.

From the characterization of these groups, the sustainability projects that showed interaction were duly identified, and hence the public goods game was proposed, as the best way to represent the dilemma faced by the groups, particularly as regards the public good notion. Regarding the type of game, the details on the gains for cooperation were proposed as follows:

Table 6: Sustainability project with which the interest group has an interface, and proposal of economic games

\begin{tabular}{|c|c|c|c|}
\hline Group & $\begin{array}{l}\text { Joint projects in the } \\
\text { field of sustainability }\end{array}$ & Public goods & Proposed games \\
\hline Fishermen & $\begin{array}{l}\text { - Monitoring of } \\
\text { income and } \\
\text { socioeconomics of } \\
\text { fishing in the reservoir; } \\
\text { - Mobilization for } \\
\text { cleaning the reservoir; } \\
\text { - Mobilization for } \\
\text { collecting garbage } \\
\text { from the reservoir; } \\
\text { - Transfer of } \\
\text { technology for } \\
\text { processing fisheries }\end{array}$ & $\begin{array}{l}\text { - Fish and its } \\
\text { potential as } \\
\text { commercial and } \\
\text { subsistence } \\
\text { income for the } \\
\text { fishermen; } \\
\text {-The donation in } \\
\text { the game } \\
\text { represents a proxy } \\
\text { of cooperation, } \\
\text { indicating how } \\
\text { much the } \\
\text { fishermen are } \\
\text { willing to maintain } \\
\text { the public good, } \\
\text { even to the } \\
\text { detriment of } \\
\text { immediate } \\
\text { individual benefit } \\
\text { (retention of the } \\
\text { amount) }\end{array}$ & $\begin{array}{l}\text { Voluntary contribution (public good): } \\
\text { - The fishermen - in a game of } 12 \text { rounds } \\
\text { ( } 6 \text { for control; and } 6 \text { for treatments, named } \\
\text { as 'reservoir game') - will receive a } \\
\text { monetary amount, which they must } \\
\text { choose to donate for the care and } \\
\text { preservation of the reservoir, or keep for } \\
\text { their own profit. } \\
\text { A group of } 6 \text { individuals will be used, as } \\
\text { defined in the section } 3 \text { (methodological } \\
\text { procedures). }\end{array}$ \\
\hline
\end{tabular}

Source: Prepared from data collection

Checking willingness to cooperate in actions geared to sustainability, as well as examining the role of punishment and reward mechanisms is relevant for the corporation to obtain subsidies for the establishment and maintenance of long lasting relationships with these interest groups. For this, the possibility for communication between those involved (particularly direct, face-to-face communication), the long-term horizon of relationships, and the reputation of the power plant can represent factors that support stakeholders' motivation, which in turn raises the chances for cooperation between all parts involved (Ostrom, 2010). 


\section{Final Considerations}

The present study sought to present a proposal for an association between two areas of research still poorly integrated - the contributions that behavioural economics and crowding out theory can bring to the analysis of actions envisaging sustainability, which demand the cooperation between a hydroelectric power plant and the fisheries community that make a living out of its reservoir. It can be added that most research, based on the application of economic experiments, focuses on two aspects:

- Analyzes decisions targeting cooperation in public goods based on a dummy scenario - created in university laboratories - predominantly with the participation of students (Weber and Dawes, 2005; Houser et al., 2012; Dannenberg, 2016; Boosey, 2017);

- Analyzes decisions targeting cooperation based on field experiments in rural communities (Cardenas, 2000; Cardenas and Ostrom, 2004; Henrich et al., 2005; Vollan, 2008; Narloch et al., 2012), envisaging the understanding of the dynamics of cooperation between these groups, as well as the factors that may interfere in this dynamics. In this case, research generally involved a combination of (qualitative and experimental) methods, making use of specific control variants, and - sometimes - considering specific contexts in which these communities exist, in terms of social norms, restriction of resources, forms of subsistence. The present proposal is embedded in this latter current, and can be synthesized as follows;

Table 7: Experiment proposal

\begin{tabular}{|c|c|}
\hline \multicolumn{2}{|c|}{ Punishment and evaluation of crowding out effect } \\
\hline $\begin{array}{c}\text { Without } \\
\text { punishment (control) }\end{array}$ & With high level of punishment \\
\hline \multicolumn{2}{|c|}{ Reward and evaluation of crowding out effect } \\
\hline Without reward (control) & With high level of individual reward \\
\hline
\end{tabular}

Source: Prepared by the author, based on specialized literature

It is recognized that economic field experiments lose part of their internal validity and potential for replication when compared to laboratory experiments (Roe and Just, 2009). However, to approach the reality of local organizations and identify the heterogeneity of the stakeholders with which the hydroelectric power plant interacts represents a relevant aspect to be considered in decision-making about cooperation (Chakravarty and Fonseca, 2014).

Still with respect to the proposal of use of economic behavioural experiments, it is justified due to the nature of the information one wishes to obtain, which can hardly be obtainable by means of performing predominantly qualitative studies, or by exclusively applying questionnaires. Cardenas and Carpenter (2006), for example, recommend the adoption of this procedure to evaluate issues related to decision-making of agents and groups, especially on matters related to preferences, risk, and willingness to cooperate. Due to this methodological option, it is important to observe the need to strictly comply with the protocol of manipulation of variables and the operationalization of the experiment itself. This involves specific procedures in the recruitment of potential participants phase, explanations, and stimuli prior to the game, game conduction, and even a follow-up to the experiment (Kreps, 1990; Henrich et al., 2005; Cardenas, 2000; Cardenas and Carpenter, 2006; Howe et al., 2016).

The current proposal finally wishes to contribute to the refinement of research on hydroelectric power plants stakeholders' willingness to cooperate, representing a still on-going development of an opportunity for research on this theme. From a practical standpoint, this study can help in the acquisition of relevant information about the applicability and efficiency of punishment and reward mechanisms related to cooperation between a power plant and its local stakeholders, either in support of future negotiations and agreements or in bargaining situations when groups present their demands. One can only hope to have also contributed to the improvement of management of contractual agreements between corporations and local stakeholders in projects targeting sustainability; to reduce any transaction costs, particularly in long-term relationships; complement the contents of contracts, drafting obligations/duties of the parties involved, applicable penalties and incentives for contractual compliance; and minimize the possibilities for conflict and disagreement between partners. 
The conduction of similar studies in other power plants with recent impact on local communities, as is the case of Belo Monte power plant (Oliveira et al., 2016), and with other players can also aid to the validation of this proposal. The limitations of this research include a relatively low number of people interviewed and the consequent need for continuity in validation and confirmation of the public goods in each game.

\section{REFERENCES}

[1] Albers, S. (2010) Configurations of Alliance Governance Systems. Schmalenbach Business Review, 62(7): 204-233. Retrieved from: https://ssrn.com/abstract=1707433.

[2] Anderson, C. and Putterman, L. (2006). Do non-strategic sanctions obey the law of demand? The demand for punishment in the voluntary contribution mechanism. Games and Economic Behavior 51(1): 1-24. DOI: 10.1016/j.geb.2004.08.007

[3] Andreoni, J. (1988). Why free ride? Strategies and learning in public goods experiments. Journal of Public Economics, 37: 91-304. DOI: 10.1016/0047-2727(88)90043-6

[4] Andreoni, J., Harbaugh, W. and Vesterlund, L. (2003). The Carrot or the Stick: Rewards, Punishments, and Cooperation. American Economic Review, 93 (3): 893-902.DOI: 10.1257/000282803322157142

[5] Balliet, D.; Langer, P.A.M.; and Mulder, L.D (2011). Reward, Punishment, and Cooperation: A MetaAnalysis. Psychological Bulletin, 137(4): 594-615. DOI: 10.1037/a0023489

[6] Boosey, L.A.N. (2017). Conditional cooperation in network public goods experiments. 18(19): 1-9. DOI: 10.1016/j.socec.2017.01.001

[7] Bond, A.; Pope, J.; Saunders, A.M. and Retief, F. (2016). A game theory perspective on environmental assessment: what games are played and what does this tell us about decision making rationality and legitimacy?. Environmental Impact Assessment Review 57(2): 187-194. DOI: 10.1016/j.eiar.2016.01.002

[8] Bochet, O.; Page, T. and Putterman. L. (2006). Communication and punishment in voluntary contribution experiments, Journal of Economic Behavior \& Organization 60(1): 11-26: DOI: 10.1016/j.jebo.2003.06.006

[9] Bowles, S.; Reyes, S.P. Economic Incentives and Social Preferences: Substitutes or Complements? Journal of Economic Literature 50 (2): 368-425. DOI: 10.1257/jel.50.2.368

[10] Brazil. Ministério de Minas e Energia (MME). (2015a). Plano Decenal de Expansão de Energia 2024. Brasília: MME/EPE. Retrived from: www.epe.gov.br/pt/publicacoes-dados-abertos/publicacoes/PlanoDecenal-de-Expansao-de-Energia-2024

[11] Brazil. Ministério de Minas e Energia (MME). (2015b). BRIC Energy Indicators. Retrived from: http://www.mme.gov.br/documents/10584/3580500/06+-+BRIC+Energy+Indicators +\%28year++2015\%29+\%28PDF\%29/470882ae-364b-4d37-8463-8f1220016315?version =1.2

[12] Cardenas, J.C. and Carpenter, J. (2006). Behavioral Development Economics: Lessons from field labs in the developing world. The Journal of Development Studies 44(3): 311-338. DOI: 10.1080/00220380701848327

[13] Cardenas, J.C, Janssen, M.A. and Bousquet, F. (2013). Dynamics of Rules and Resources: Three New Field Experiments on Water, Forests and Fisheries. In: List, J. Price, M, Elgar, E. Handbook on Experimental Economics and the Environment, Cheltenham, 319-345.

[14] Cardenas, J.C. and Ostrom, E. (2004). What do people bring into the game: experiments in the field about cooperation in the commons. Capri working paper no. 32. International Food Policy Research Institute. Retrived from: http://citeseerx.ist.psu.edu/viewdoc/download?doi=10.1.1.192.1453\&rep=rep1\&type=pdf

[15] Cardenas, J.C.; Stranlund, J. and Willis, C. (2000). . World Development 28(10): 1719-1733. DOI: 10.1016/S0305-750X(00)00055-3

[16] Carpenter, J. (2007). Punishing free-riders: how group size affects mutual monitoring and the provision of public goods. Games and Economic Behavior 60(1): 31-51. DOI: 10.1016/j.geb.2006.08.011.

[17] Carroll, A. B. (1989). Business and society: Ethics and stakeholder management. Cincinnati: South-Western.

[18] Castillo, D., Bousquet, F.; Janssen, M.A.; Worrapimphong, K. and Cardenas, J.C.(2011). Context matters to explain field experiments: results from Thai and Colombian fishing villages. Ecological Economics, 70(9), 1609-1620. DOI:10.1016/j.ecolecon.2011.05.011

[19] Chaudhuri, A. (2010). Sustaining cooperation in laboratory public goods experiments: a selective survey of the literature. Experimental Economics, 14, 47-83. DOI:

[20] Chakravarty, S. and Fonseca, M.A. (2010). The effect of social fragmentation on public good provision: An experimental study. Journal of Behavioral and Experimental Economics 53 (1): 1-9. DOI: 10.1016/j.socec.2014.07.002

[21] Choi, J.K. and Ahn, T.K. (2013). Strategic reward and altruistic punishment support cooperation in a public goods game experiment. Journal of Economic Psychology 35 (4): 17-30.

DOI: 10.1016/j.joep.2013.01.001 
[22] Cornell, B. and Shapiro, A.C. (1987). Corporate stakeholders and corporate finance. Financial Management 16(1): 5-14. DOI: 10.2307/3665543

[23] Dannenberg, A. Non-binding agreements in public goods experiments. Oxford Economic Papers 68 (1): 279-300. DOI:10.1093/oep/gpv048

[24] Dickinson, D. and Villeval, M.C. (2008). Does monitoring decrease work effort? The complementarity between agency and crowding-out Theories. Games and Economic Behavior, 63(1): 56-76. DOI: 10.1016/j.geb.2007.08.004

[25] Dombi, M., Kuti, I. and Balogh, P. (2014). Sustainability assessment of renewable power and heat generation technologies. Energy Policy 67(4): 264-271. DOI: 10.1016/j.enpol.2013.12.032

[26] Dominique, J.F.; Fischbacher, U.; Treyer, V. Schellhammer, M.; Schnnyder, U.; Buck, A. and Fehr, E. (2004). The neural basis of altruistic punishment. Science 305(5688): 1254-1258. Retrieved from: http://citeseerx.ist.psu.edu/viewdoc/download?doi=10.1.1.395.5243\&rep=rep1\&type=pdf

[27] Du, J.; Wu, B. and Wang. L. (2016). Aspiration dynamics and the sustainability of resources in the public goods dilemma. Physics Letters A 380(16): 1432-1436. Doi: /10.1016/j.physleta.2016.02.039

[28] Egas, M. and Riedl. A. (2008). The economics of altruistic punishment and the maintenance of cooperation. Proceeding's of Royal Society..275: 871-878. DOI: 10.1098/rspb.2007.1558

[29] Emery, T. J., Tisdell, J., Green, B. S., Hartmann, K., Gardner, C., and León, R. (2015). An experimental analysis of assignment problems and economic rent dissipation in quota managed fisheries. Ocean and Coastal Management, 106(3): 10 -28. DOI: 10.1016/j.ocecoaman.2015.01.008

[30] Engert, S.; Rauter, R. and Baumgartner, R.J. (2016). Exploring the integration of corporate sustainability into strategic management: a literature review. Journal of Cleaner Production 112(4): 2833-2850. DOI: 10.1016/j.jclepro.2015.08.031

[31] Ertan, A., Page, T. and Putterman, L. (2009). Who to punish? Individual decisions and majority rule in mitigating the free rider problem. European Economic Review 53(5): 495-511. DOI:10.1016/j.euroecorev.2008.09.007

[32] Falk, A.; Fehr, E. and Fischbacher, U. Driving Forces behind Informal Sanctions. Econometrica 73(6): 2017-2030.

[33] Fehr, E. and Falk, A. (2002). Psychological foundations of incentives. European Economic Review 46(1): 687-724. DOI: 10.1016/S0014-2921(01)00208-2

[34] Fehr, E., and Gachter, S. (2000). Cooperation and punishment in public goods experiments. American Economic Review, 90(4): 980-994. DOI: 10.1257/aer.90.4.980

[35] Frey, B.S. and Jegen, R. (2001). Motivation crowding theory. Journal of Economic Surveys 15(1): 589-611. DOI: 10.1111/1467-6419.00150

[36] Frey, B. S. and Stutzer, A. (2006). Environmental Morale and Motivation. Working Paper, 17. Center for Research in Economics, Management and Arts (CREMA). DOI: 10.2139/ssrn.900370

[37] Gächter, S., Renner, E. and Sefton, M. (2008). The long run benefits of punishment. Science, v.322(5907): 1510-1520. DOI: 10.1126/science.1164744

[38] Gneezy, U., Meier, S. and Biel, P.R. (2011). When and why incentives (don't) work to modify behavior. The Journal of Economic Perspectives 25 (4):191-209. DOI: 10.1257/jep.25.4.191

[39] Godoy, A. S. (2006). Estudo de caso qualitativo. In Godoi, C. K., Bandeira-de-Mello, R., \& Silva, A. B. (Orgs.). Pesquisa qualitativa em estudos organizacionais: paradigmas, estratégias e métodos (1a ed.). São Paulo: Saraiva.

[40] Han, M.Y; Sui, X.; Huang, Z.L.; Wu, X.; Xia, X.H.; Hayat, T. and A. Alsaedi. Bibliometric indicators for sustainable hydropower development. , 47(12): 231-238. DOI: 10.1016/j.ecolind.2014.01.035

[41] Henrich, J., Mcelreath, R.; Barr,A.; Barrett, J.E.C.; , Bolyanatz, A.; Cardenas, J.C.; Gurven, M.; Gwako, E.; Henrich, N.; Lesorogol, C.; Marlowe, F.;Tracer, D. and Ziker J. (2005). "Economic man" in crosscultural perspective: Behavioral experiments in 15 small-scale societies. Behavioral and Brain Sciences, (28):795-855. DOI: 10.1017/S0140525X05000142

[42] Herrmann, B.; Thöni, C.; Gächter, S. Antisocial Punishment Across Societies. Science 319: 1362-1367. DOI: 10.1126/science.1153808

[43] Howe, E. L., Murphy, J. J., Gerkey, D., and West, C. T. (2016). Indirect reciprocity, resource sharing, and environmental risk: Evidence from field experiments in Siberia. PloS one, 11(7), e0158940. DOI: 10.1371/journal.pone.0158940

[44] Houser, D.; Xiao, E.; Mccabe, K. and Smith, V. (2008). When punishment fails: Research on sanctions, intentions and non-cooperation. Games and Economic Behavior, 62(2): 509-532. DOI: 10.1016/j.geb.2007.05.001

[45] International Energy Agency (2017). World Energy Outlook 2017. Retrieved from: https://www.iea.org/weo2017/

[46] IHA (International Hydropower Association). (2006). Sustainability assessment protocol, July. Retrieved from: https://www.hydropower.org/topics/featured/hydropower-sustainability-assessmentprotocol 
[47] Janssen, M.A., Bousquet, F.; Cardenas, J.C.; Castillo, D. and Worrapimphong, K. (2012). Field Experiments of Irrigation Dilemmas. Agricultural Systems, 109 (1), 65-75. DOI: 10.1016/j.agsy.2012.03.004

[48] Janssen, M.A., Bousquet, F.; Cardenas, J.C.; Castillo, D.; and Worrapimphong, K. (2012). Breaking the elected rules in field experiments on forestry resources Ecological Economics, 90: 132-139. DOI: 10.1016/j.ecolecon.2013.03.012

[49] Jiang, H.; Qiang, M. and Lin, P. (2016). A topic modeling based bibliometric exploration of hydropower research. Renewable and Sustainable Energy Reviews 57(3): 226-237. DOI: 10.1016/j.rser.2015.12.194

[50] Jin, B.Z. and Bai, Y. (2011). Sustainable development and long-term strategic management. Embedding a long-term strategic management system into medium and long-term planning. World Future Review. 3(2):49-69. DOI: 10.1177/194675671100300208

[51] Kreps, D. M. (1990). Corporate Culture and Economic Theory. In: Alt, j.e.; Shepsle, k.a. eds. (1990), Perspectives on Positive Political Economy, Cambridge, England: Cambridge University Press, 90-143.

[52] Kumakawa, T. (2013). Social rewards and sanctions: A voluntary contribution mechanism experiment. Journal of Neuroscience, Psychology, and Economics, 6(3), 189-200. DOI: 10.1037/npe0000011

[53] Langtry, B. (1994). Stakeholders and the moral responsibilities of business. Business Ethics Quarterly, 4: 431-443. DOI: 10.2307/3857342

[54] Lin, P.S.S. and Liu, Y.L. (2016). Niching sustainability in an Indigenous community: protected areas, autonomous initiatives, and negotiating power in natural resource management. Sustainability Science, 11(1): 103-113. DOI: $10.1007 / \mathrm{s} 11625-015-0294-8$

[55] Liu, J., Zuo J., Sun Z., Zillante, G., and Chen, X. (2013). Sustainability in hydropower development - a case study. Renewable and Sustainable Energy Reviews, 19: 230-237. DOI: 10.1016/j.rser.2012.11.036

[56] Lozano, R. (2007). Collaboration as a Pathway for Sustainability. Sustainable Development, 15(6):370381. DOI: $10.1002 / \mathrm{sd} .322$

[57] Masclet, D., Noussair, C., Tucker, S., Villeval, M.-C. (2003). Monetary and Non-Monetary Punishment in the Voluntary Contributions Mechanism. American Economic Review 93(1):366-380

[58] Mayumi, K. and Tanikawa, H. (2012). Going beyond energy accounting for sustainability: energy, fund elements and the economic process. Energy, 37(1):18-26. DOI: 10.1016/j.energy.2011.04.050

[59] Moreira, J. M., Cesaretti, M. A., Carajilescov, P., Maiorino, J. R. (2015). Sustainability deterioration of electricity generation in Brazil. Energy Policy, 87(December): 334-346. DOI: 10.1016/j.enpol.2015.09.021

[60] Morinoto, R. (2013). Incorporating socio-environmental considerations into project assessment models using multicriteria analysis: A case study of Sri Lankan hydropower projects. Energy Policy 59(c): 643653. DOI: 10.1016/j.enpol.2013.04.020

[61] Morrison-Saunders, A., Pope J.; Gunn, J.; Bond, A. and F. Retief. (2014). Strengthening impact assessment: a call for integration and focus. Impact Assess Project Appraisal 32(1):2 - 8. DOI: 10.1080/14615517.2013.872841

[62] Narloch, U.; Pascual, U. and Drucker, A.G. (2012). Collective Action Dynamics under External Rewards: Experimental Insights from Andean Farming Communities. World Development 40(10):2096-2107. DOI: 10.1016/j.worlddev.2012.03.014

[63] Nikiforakis, N. (2004). Punishment and Counter-punishment in Public Goods Games: Can we still govern ourselves? Experimental 0403001, EconWPA.

[64] Nikiforakis, N. and Normann, H. (2008). A comparative statics analysis of punishment in public good experiments. Experimental Economics, 11(1): 358-369. DOI: 10.1007\%2Fs10683-007-9171-3

[65] Oliveira, C.M.; Rebello, F.K.; Santos, M.A.S. and Santana, A.C. (2016). Usina hidrelétrica de Belo Monte: Percepções dos atores locais quanto aos impactos socioeconômicos e ambientais. Espacios, 37(12): 1-10. Retrived from: www.revistaespacios.com/a16v37n12/16371205.html

[66] Ostrom, E. (2010). Beyond Markets and States: Polycentric Governance of Complex Economic Systems. American Economic Review 100(3): 641-672. DOI: 10.1257/aer.100.3.641

[67] Perc M, Wang Z. (2010) Heterogeneous Aspirations Promote Cooperation in the Prisoner's Dilemma Game. PLOS ONE 5(12): e15117. DOI: 10.1371/journal.pone.0015117

[68] Porter, M.E. and Kramer, M. (2006). Strategy and society: the link between competitive advantage and corporate social responsibility. Harvard Business Review 84(12): 78-92. Retrived from: kantakji.com/media/3307/1135.pdf

[69] Purwanto, W.W. and Afifah., N. (2016). Assessing the impact of techno socioeconomic factors on sustainability indicators of micro hydropower projects in Indonesia: A comparative study. Renewable Energy, 93(c,): 312-322. DOI: 10.1016/j.renene.2016.02.071

[70] Reuben,E. and Riedl, A. (2013). Enforcement of contribution norms in public good games with heterogeneous populations. Games and Economic Behavior, 77(1): 122-137. DOI: $10.1016 /$ j.geb.2012.10.001

[71] Roe, B. and Just, D. (2009). Internal and external validity in economics research: tradeoffs between experiments, field experiments, natural experiments and field data. American Journal of Agricultural Economics, 91(5): 1266-1271. DOI: 10.1111/j.1467-8276.2009.01295.x 
[72] Robert, K.R. and Broman, G. (2017). Prisoner's dilemma misleads business and policy making. Journal of Cleaner Production, 140(1): 10-16. DOI: 10.1016/j.jclepro.2016.08.069

[73] Rockenbach, B, and Milinski, M. (2006). The efficient interaction of indirect reciprocity and costly punishment. Nature, 444(7120): 718-723. DOI: 10.1038/nature05229

[74] Sefton, M., Shupp, R. and Walker. J. (2007). The effect of rewards and sanctions in provision of public goods. Economic Inquiry 45(4), 671-690. 10.1111/j.1465-7295.2007.00051.x

[75] Sell, J.; Chen, Z.Y.; Hunter-Holmes, P. and Johansson, A. (2002). A cross-cultural comparison of public good and resource good settings. Social Psychology Quarterly 65(3): 285-297. DOI: 10.2307/3090124

[76] Soest, D.V.; Stoop, J. and Vyrastekova, J. (2016). Toward a delineation of the circumstances in which cooperation can be sustained in environmental and resource problems. Journal of Environmental Economics and Management, 77(5): 1-13. DOI: 10.1016/j.jeem.2015.12.004

[77] Sturm, B. and Weimann, J. (2006). Experiments in environmental economics and some close relatives. Journal of Economic Surveys, 20 (3): 419-457. DOI: 10.1111/j.0950-0804.2006.00285.x

[78] Travers, H., Clements, T., Keane, A., \& Milner-gulland, E. (2011). Incentives for cooperation: The effects of institutional controls on common pool resource extraction in Cambodia. Ecological Economics, 71, 151-161. DOI: 10.1016/j.ecolecon.2011.08.020

[79] Vollan, B. (2008). Socio-ecological explanations for crowding-out effects from economic field experiments in southern Africa, Ecological Economics, 6 7(4): 560-573. DOI: 10.1016/j.ecolecon.2008.01.015

[80] Vyrastekova, J.; Soest, V. D. (2008). Experimental Economics 11(1), pp 53-65 DOI: 10.1007/s10683006-9153-x

[81] Walker, J. and M. Halloran. (2004). Rewards and sanctions and the provision of public goods in oneshot settings. Experimental Economics, 7(3): 235-247. DOI: 10.1023/B:EXEC.0000040559.08652.51

[82] Williamson, O. E. (1985). The Economic Institutions of Capitalism . New York: The Free Press.

[83] Weber, R. and Dawes, R. (2005). Behavioral Economics. In: Smelser, N.J. and Swedberg, R. (2005). The handbook of economic sociology, 2, p.90-108, 2005.

[84] Yüksel, I. (2010). Hydropower for Sustainable Water and Energy Development. Renewable and Sustainable Energy Reviews, 14(1): 462-469. DOI: 10.1016/j.rser.2009.07.025

[85] Zijp, M.C., Heijungs, R., Van Der Voet, E., Van De Meent, D., Huijbregts, M.A.J., Hollander, A. and Posthuma, L. (2015). An Identification Key for Selecting Methods for Sustainability Assessments. Sustainability, $7(1)$ : 2490-2512. DOI: 10.3390/su7032490

[86] Zhao, X., Liu, L., Liu, X., Wang, J., and Liu, P. (2012). A critical analysis of the development of China's hydropower, Renewable Energy, 44(1): 1-6. DOI: 10.1016/j.renene.2012.01.005

Received: 2018-05-25

Accepted: 2018-06-30

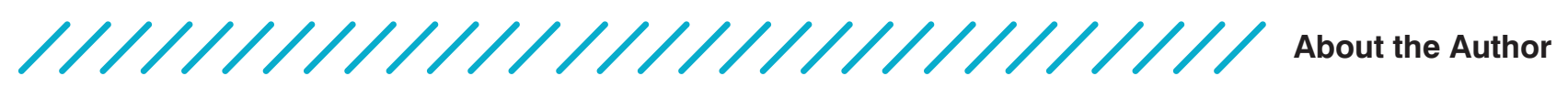

Fabricio Baron Mussi

Pontifícia Universidade Católica do Paraná, Brazil fabricio_mussi@hotmail.com

Bachelor's and Master' degree at Business at Federal University of Parana and a PhD student at Business of Pontifícia Universidade Católica do Paraná. He is currently a contract manager at Itaipu Hydroelectric Power Plant. He has experience in Business, acting mainly in the following subjects: sustainability; economic behaviour; finances.

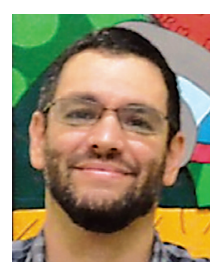

\section{Ubiratã Tortato \\ Pontifícia Universidade Católica do Paraná, Brazil ubirata.tortato@pucpr.br}

Bachelor's and Master's at Business from Universidade Federal do Paraná and a PhD at Production Engineering from Universidade de São Paulo. He is currently a full professor at The Pontifícia Universidade Católica do Paraná and Chief-Editor of REBRAE. He has experience in Business, acting mainly in the following subjects: sustainability, SSCM, eco-efficiency, cooperatives and sustainable universities.

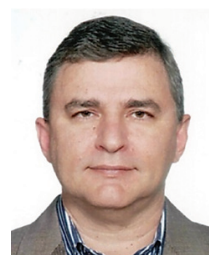

